\title{
ACCESS DETERMINANTS AND USE OF HEALTH SERVICES AMONG THE ELDERLY
}

\author{
DETERMINANTES DO ACESSO E UTILIZAÇÃO DOS SERVIÇOS DE SAÚDE \\ ENTRE IDOSOS
}

\section{Darlene Mara dos Santos TAVARES ${ }^{1}$; Amanda Queiroz de SOUZA ${ }^{2}$; Maycon Sousa PEGORARI ${ }^{3}$; Nayara Cândida GOMES ${ }^{4}$; Renata Afonso BARCELOS ${ }^{5}$; Paula Beatriz de OLIVEIRA ${ }^{4}$}

1. Enfermeira, Professora Associada do Curso de Graduação em Enfermagem, Universidade Federal do Triângulo Mineiro - UFTM, Uberaba, MG, Brasil. darlenetavares@enfermagem.uftm.edu.br; 2. Discente do Curso de Graduação de Terapia Ocupacional, UFTM, Uberaba, MG, Brasil; 3 Fisioterapeuta, Professor Assistente do Curso de Graduação em Fisioterapia, Universidade Federal do Amapá, Macapá, AP, Brasil; 4. Enfermeira, Doutoranda do Programa de Pós-Graduação stricto sensu em Atenção à Saúde, UFTM, MG, Uberaba, Brasil; 5 Enfermeira, Mestre em Atenção à Saúde - UFTM, Uberaba, MG, Brasil

\begin{abstract}
: this study aimed to describe the characteristics related to access to and use of health services, and verify factors associated with the use of services among the elderly. This is a cross-sectional analytical study conducted with 705 urban elderly in Uberaba/Minas Gerais. Were used: structured instrument related to socioeconomic data, Katz, Lawton and Brody scales and Fried Fragility Phenotype; and questionnaire from the National Survey by Domicile Sample for access and use of health services. The procedure was the descriptive and logistic regression analysis $(\mathrm{p}<0.05)$. It was found that $86.2 \%$ accessed the same place or the same doctor when they needed care; $86.5 \%$ consulted a doctor in the last 12 months; $85.2 \%$ were using continuous medication, from this $40.4 \%$ received part of their medicines; and those who did not receive all medications, $86.1 \%$ effected the purchase. Most went to the dentist last three years or more $(54.2 \%)$ while $21.7 \%$ for less than one year, and $16.9 \%$ used health services in the two weeks preceding the interview. Polypharmacy (OR: 2.88; $\mathrm{p}=0.026)$ and the perception of negative health (OR: 1.89; $\mathrm{p}=0.009)$ were consolidated as factors associated with the use of health services. The knowledge of standard consumption and related factors enables the service organization as the presented characteristics.
\end{abstract}

KEYWORDS: Elderly. Health system. Health services for the elderly. Access to health services.

\section{INTRODUCTION}

The increased longevity of the population is changing the epidemiological profile in Brazil with increased mortality from non-communicable diseases (NCDs) to the detriment of infectious and parasitic diseases (GEOGRAPHY AND STATISTICS BRAZILIAN INSTITUTE, 2012). In this perspective, aging confers changes in demands for health services with greater demand for elderly (DELLAROZA et al., 2013; VERAS, 2009). Hospital admissions are more frequent and the bed occupancy time is longer when compared to other age groups (VERAS, 2009).

The use of health services for the elderly is multifactorial and is related to the individual and structural factors and aspects of the social environment where the elderly is inserted (DELLAROZA et al., 2013). The access is understood as an element of the health system that covers the entry and treatment follow-up (TEIXEIRA; OLIVEIRA; SILVA, 2011). It is an issue that involves political, economic, social, organizational, technical and symbolic aspects, in determining directions for the universalization of its attention (ASSIS; JESUS, 2012).

According to the National Health Survey (NHS) performed in 2013, 83.5\% of elderly sought medical service, exceeding the national average compared to other age groups. The same group reported the lowest percentage of dentist appointments (28.9\%) (GEOGRAPHY AND STATISTICS BRAZILIAN INSTITUTE, 2015). A domicile survey conducted with elderly enrolled in public services in Guarapuava/Paraná found that the health services most used in the last three months were the medical consultation $(49.6 \%)$ and clinical examinations (38.4\%); while $55.6 \%$ reported not seeking dental services (PILGUER; MENON; MATHIAS, 2013).

In contrast, other studies mentioned this issue in specific conditions and/or different contexts and/or cutout, namely: elderly people with or without health insurance (HERNANDES et al., 2012.), physical activity participants (VIRTUOSO et al., 2012), elderly with chronic pain (DELLAROZA et al., 2013) and disability (FIALHO et al., 2014).

In this perspective, the literature points to factors associated with the use of health services the 
worst self-perceived health $(\mathrm{OR}=1.92)$, disease presence $(\mathrm{OR}=2.73)$, private health insurance $(\mathrm{OR}=1.57)$ and female $(\mathrm{OR}=1.55)$ (LOUVISON et al., 2008). More recent studies showed the female (PILGUER; MENON; MATHIAS, 2013), increasing age (BASTOS; HARZHEIM; SOUSA, 2014), the presence of more intense chronic pain, the most recent and with work impact (DELLAROZA et al., 2013) and functional disability among elderly (FIALHO et al., 2014).

Studies that address the access and use of health services contribute to the perception of the consumption pattern, which allows health planning actions of the elderly population, decreasing spending with the high complexity services and specialties. It also favors the proposal of appropriate public policies and the development of care models (PILGUER; MENON: MATHIAS, 2013), from the observed population context. Thus, since the limitation of current investigations that relate the access determinants to the use of health services among the elderly and to deepen discussions about the subject, this study aimed to describe the characteristics related to access and use of health services; and verify the factors associated with the use of services among the elderly.

\section{MATERIAL AND METHODS}

Domicile, observational, analytical and cross-sectional survey conducted in 2014 with 705 elderly residents in the urban area of the city of Uberaba/Minas Gerais.

The sample size calculation considered an accuracy of $3.5 \%$ and a $95 \%$ confidence interval, for a finite population of 36,703 elderly, reaching a sample of 684 subjects. Considering a sampling loss of $20 \%$, the maximum number of interviews attempts was 855 .

The conglomerate sample in multiple stages was used for the definition of the urban population. The first stage proceeded with the arbitrary selection of $50 \%$ of the census tracts in each municipality through systematic sampling organizing a single list of sectors but identifying the neighborhood to which it belongs. Some urban census tracts in the city of Uberaba/Minas Gerais is 409, and 204 selected. The sample interval (SI) was calculated using the following formula: SI=Nct/nsct; where Nct is the total number of census tracts and nsct the number of selected census tracts $(\mathrm{SI} \approx 2)$. The first census tract was randomly selected and the other according to SI. The list of sectors was ordered in ascending numerical order, for the selection purpose.

In the second stage, the number of elderly people to be interviewed according to sample calculation (724) was divided by the number of census tracts randomly selected in the first stage (204), obtaining the value of 3,55 elderly, rounded to four elderly by census tract. In this context, considering the sample size calculation, 204 census tracts and four people per sector, originate from a sample of 816 elderly.

Inclusion criteria were: aged equal or over 60 years old, being a resident in urban areas, do not having cognitive decline, being able to walk around, and allowed the use of assistive devices for gait (cane, crutch or walker) and agree participating in the research by signing the Informed Consent Form (ICF). The following were considered as exclusion and losses criteria: not located after three attempts by the interviewer; hospitalization condition; neurological disorders that impaired the evaluations performance; those who have not completed all the tests for fragility; and sectors without elderly, homes and that have not completed the number of elderly. Thus, 705 elderly were interviewed.

Ten interviewers were selected, with previous experience in data collection, and were trained in the completion of the data collection instruments and how to approach the interviewee. Interviewers noted the complications (absences, refusals and other) on the field sheet. Field supervisors conferred each interview and verified completion and consistency of items, ensuring quality control. Systematics meetings were performed between researchers, supervisors and interviewers for training, monitoring and guidelines for data collection.

The procedure was initially cognitive assessment by the Mini Examination of Mental State (MEMS), translated and validated in Brazil (BERTOLUCCI et al., 1994). The cutoff point for cognitive decline considered the respondent's educational level, corresponding 13 points for illiterates, 18 points or less for those 1 to 11 years of study and 26 points for higher education superior than 11 years (BERTOLUCCI et al., 1994).

The socio-demographic and economic data, anthropometric and clinical variables (self-perceived morbidities, medication use, and self-perceived health), were measured from structured form designed by the Research Group on Collective Health of UFTM.

Functional capacity was assessed by performing basic activities of daily living (BADL), using the Katz Index, adapted to Brazilian reality (LINO et al., 2008), which consists of six items that measure the performance of person in self-care activities (LINO et al., 2008). They also measured 
the instrumental activities of daily living (IADL) through Lawton and Brody Scale, adapted in Brazil (SANTOS, VIRTUOSO JUNIOR, 2008). This scale consists of seven items with scores ranging from 7 to 21 points (SANTOS; VIRTUOSO JUNIOR, 2008).

The presence of frailty syndrome was verified using the five items described as components of frailty phenotype proposed by Fried et al. (2001), namely: unintended weight loss; decreased muscle strength, self-perceived exhaustion and/or fatigue, slowness and low level of physical activity. The information detailed for the parameters adopted for each component were previously published (PEGORARI; TAVARES, 2014). Elderly with three or more of these items were classified as frail and those with one or two items, such as pre-fragile and those with absence score in the criteria, non-fragile (FRIED et al., 2001).

The access and the use of health services were assessed through two sections of the questionnaire of the National Survey by Domicile Sample (NSDS) (GEOGRAPHY AND STATISTICS BRAZILIAN INSTITUTE, 2010).

The study variables were gender (male and female); age group in years (60l-70, 70I-80, 80 years old and over); marital status (single, married, widowed or separated); education in years (without education, 1-14, and 5 and over); individual income in minimum wages (no income, up to 1 minimum wage, $11-3$ and 3 and over); self-perceived morbidities (none, 1-14 and 5 and over); drug use (none, 1-14 and 5 and over); functional capacity in BADL: bathing, dressing, toileting, transference, sphincter control, food; functional disability in BADL (dependent and independent); functional capacity in IADL: using the phone, to travel, shopping, preparing meals, performing housework, medication use and handle money; functional disability in IADL (dependent and independent); self-perceived health (positive and negative); frailty: unintentional weight loss in the last year; muscle strength; self-perceived exhaustion; gait performance and level of physical activity; use and access to health services: access looking the same place of health care, local demand for health care, medical consultation in the last 12 months, use of continuous medications, dentist appointments; use services related to their health in the last two weeks, attendance reason, number of times and local; nonattendance reason; demand for health care for the same reason in the last two weeks, local, non- attendance reason, primary health care which received nature of the service, health insurance coverage, payment for the service, services provided by SUS, received care assessment and medication use.

The collected data were entered by two people, with double entry and checked for inconsistencies between the two bases. After the necessary corrections in the original interview, the database was transported to the Statistical Package for Social Sciences (SPSS), version 17.0, to undertake the analysis.

To characterize the population and describe the characteristics related to access to and to the use of health services; proceeded to statistical analysis through a distribution of absolute and percentage frequencies. The multivariable analysis was performed through logistic regression, preceded by bivariate analysis (chi-square test) to determine the factors associated with the use of services among the elderly. The variables that had $p<0.10$ value in the bivariate analysis were included in the regression model (enter method). The nominal variables were re-categorized to become dichotomous. The tests were considered significant at $\mathrm{p}<0.05$.

The project was submitted to the Research Ethics Committee with Human Beings of UFTM and approved with the opinion 493211. The subjects were contacted in their domiciles, introducing the objectives, the Informed Consent Form (ICF) and provided the relevant information. The interview was conducted only after the consent of the interviewee and signing the Form.

\section{RESULTS}

There was a higher percentage of female elderly $(66.8 \%)$, age group $60-70$ years $(43.1 \%)$, married $(42.0 \%), 1 \dashv 4$ years of study $(51.5 \%)$ and individual monthly income of one minimum wage $(45.0 \%)$.

It was found that $86.2 \%$ accessed the same place or the same doctor when they needed care; $86.5 \%$ made a medical consultation in the last 12 months; $85.2 \%$ were using continuous medication, of this $40.4 \%$ received part of their medicines; and those who did not receive all medications, $86.1 \%$ effected the purchase. Predominated those who went to the dentist for the last three years or more (54.2\%), while $21.7 \%$ for less than one year; and $16.9 \%$ used health services in the last two weeks before the interview, Table 1 . 
Table 1. Characteristics related to access and use of health services. Uberaba/Minas Gerais, 2014.

\begin{tabular}{lll}
\hline Indicators of access and use of health services & $\mathbf{n}$ & $\%$ \\
\hline Accessed the same doctor or the same service when they needed care & 608 & 86.2 \\
Medical consultation in the last 12 months & 610 & 86.5 \\
Use of continuous medication & 601 & 85.2 \\
Dentist appointment for the last time in the last 12 months & 153 & 21.7 \\
Used health services in the last two weeks & 119 & 16.9 \\
\hline
\end{tabular}

Regarding the associated factors, the variables of the preliminary bivariate analysis, submitted to multi-variable analysis, according to the established inclusion criteria $(\mathrm{p}<0.10)$ were: individual monthly income of up to 1 minimum wage $(\mathrm{p}=0.016)$ self-perceived negative health $(\mathrm{p}<0.001)$, five and more self-perceived morbidities $(\mathrm{p}=0.001)$, use of five and more drugs $(\mathrm{p}<0.001)$, fragile condition $(\mathrm{p}=0.011)$, functional incapacity to basic activities $(\mathrm{p}=0.051)$ and instrumental daily living $(\mathrm{p}=0.011)$, Tables 2 and 3 .

Table 2. Distribution of socio-economic characteristics according to the use of health services in the last two weeks. Uberaba/Minas Gerais, 2014.

\begin{tabular}{|c|c|c|c|c|}
\hline \multirow[b]{2}{*}{ Variables } & \multicolumn{3}{|c|}{ Use of health services in the last two weeks } & \multirow[b]{2}{*}{$\mathbf{p}^{* *}$} \\
\hline & $\begin{array}{c}\text { Yes } \\
\text { n }(\%)\end{array}$ & $\begin{array}{c}\text { No } \\
\mathbf{n}(\%)\end{array}$ & $\begin{array}{r}\text { Total } \\
\text { n }(\%)\end{array}$ & \\
\hline \multicolumn{5}{|l|}{ Gender } \\
\hline Male & $40(33.6)$ & $194(33.1)$ & $234(33.2)$ & 0.915 \\
\hline Female & $79(66.4)$ & $392(66.9)$ & $471(66.8)$ & \\
\hline \multicolumn{5}{|l|}{ Age Group } \\
\hline $60-70$ & $57(47.9)$ & $247(42.2)$ & $304(43.1)$ & 0.421 \\
\hline $70-80$ & $42(35.3)$ & $215(36.7)$ & $257(36.5)$ & \\
\hline 80 and over & $20(16.8)$ & $124(21.2)$ & $144(20.4)$ & \\
\hline \multicolumn{5}{|c|}{ Education (in years) } \\
\hline Without education & 23(19.3) & $112(19.1)$ & $135(19.1)$ & 0.394 \\
\hline $1-4$ & $67(56.3)$ & $296(50.5)$ & $363(51.5)$ & \\
\hline 5 and over & $29(24.4)$ & $178(30.4)$ & $207(29.4)$ & \\
\hline \multicolumn{5}{|l|}{ Marital status } \\
\hline Single & $8(6.7)$ & $45(7.7)$ & $53(7.5)$ & 0.927 \\
\hline Married & $53(44.5)$ & $243(41.5)$ & $296(42.0)$ & \\
\hline Widower & $46(38.7)$ & $233(39.8)$ & $279(39.6)$ & \\
\hline Separated & $12(10.1)$ & $65(11.1)$ & $77(10.9)$ & \\
\hline \multicolumn{5}{|c|}{ Individual monthly income* } \\
\hline Without income & $8(6.7)$ & $55(9.4)$ & $63(8.9)$ & 0.016 \\
\hline Up to 1 & $62(52.1)$ & $271(46.2)$ & $333(47.2)$ & \\
\hline $1-3$ & $45(37.8)$ & $186(31.7)$ & $231(32.8)$ & \\
\hline 3 and over & $4(3.4)$ & $74(12.6)$ & $78(11.1)$ & \\
\hline
\end{tabular}

*Minimum wage in 2014 ( $\mathrm{R} \$ 724,00$ - Brazilian currency); **p<0,1.

Table 3. Distribution of clinical and health characteristics according to the use of health services in the last two weeks. Uberaba/Minas Gerais, 2014.

\begin{tabular}{|c|c|c|c|c|}
\hline \multirow[b]{2}{*}{ Variables } & \multicolumn{3}{|c|}{ Use of the health services in the last two weeks } & \multirow[b]{2}{*}{$\mathrm{p}^{*}$} \\
\hline & $\begin{array}{c}\text { Yes } \\
\text { n }(\%)\end{array}$ & $\begin{array}{c}\text { No } \\
\text { n }(\%) \\
\end{array}$ & $\begin{array}{r}\text { Total } \\
\text { n (\%) }\end{array}$ & \\
\hline \multicolumn{5}{|c|}{ Self-reported morbidities } \\
\hline None & $2(1.7)$ & $27(4.6)$ & $29(4.1)$ & 0.001 \\
\hline $1-4$ & $30(25.2)$ & 234(399) & $264(37.4)$ & \\
\hline 5 and over & $87(73.1)$ & $325(55.5)$ & $412(58.4)$ & \\
\hline \multicolumn{5}{|c|}{ Medicine use } \\
\hline None & $7(5.9)$ & $84(16.0)$ & 101(14.3) & $<0.001$ \\
\hline $1-4$ & $60(50.4)$ & $327(55.8)$ & $387(54.9)$ & \\
\hline 5 and over & $52(43.7)$ & $165(28.2)$ & 217(30.8) & \\
\hline \multicolumn{5}{|l|}{ Fragility } \\
\hline Fragile & 29(24.4) & 83(14.2) & $112(15.9)$ & 0.011 \\
\hline Pre-fragile & $61(51.2)$ & $307(52.4)$ & $368(52.2)$ & \\
\hline
\end{tabular}




\begin{tabular}{lcccc}
\hline $\begin{array}{l}\text { No Fragile } \\
\text { Self-perceived health }\end{array}$ & $29(24.4)$ & $196(33.4)$ & $225(31.9)$ & \\
$\begin{array}{l}\text { Negative } \\
\text { Positive }\end{array}$ & $87(73.1)$ & $310(52.9)$ & $397(56.3)$ & $<0.001$ \\
BADL & $32(26.9)$ & $276(47.1)$ & $308(43.7)$ & \\
Dependent & & & & \\
Independent & $34(28.6)$ & $120(20.5)$ & $154(21.8)$ & 0.051 \\
IADL & $85(71.4)$ & $466(79.5)$ & $551(78.2)$ & \\
Dependent & & & \\
Independent & $83(69.7)$ & $335(57.2)$ & $418(59.3)$ & $\mathbf{0 . 0 1 1}$ \\
\hline *p<0,1; BADL: Basic Activities of Daily Living; IADL: Instrumental Activities of Daily Living & $287(40.7)$ & \\
\hline
\end{tabular}

They were consolidated as factors services $(\mathrm{p}=0.026)$ and self-perceived negative associated with the use of Polypharmacy health health $(\mathrm{p}=0.009)$, Table 4 .

Table 4. The final logistic regression model for the variables associated with the use of health services in the last two weeks. Uberaba/Minas Gerais, 2014.

\begin{tabular}{|c|c|c|c|}
\hline \multirow{2}{*}{ Variables } & \multicolumn{3}{|c|}{ The use of health services in the last two weeks } \\
\hline & OR & CI95\% & $\mathbf{p}^{*}$ \\
\hline \multicolumn{4}{|l|}{ Individual monthly income** } \\
\hline With income & & 1 & \\
\hline Without income & 0.71 & $0.32-1.57$ & 0.395 \\
\hline \multicolumn{4}{|l|}{ Self-perceived health } \\
\hline Positive & & 1 & \\
\hline Negative & 1.90 & $1.17-3.01$ & 0.009 \\
\hline \multicolumn{4}{|l|}{ Medicine use } \\
\hline None & & 1 & \\
\hline $1-4$ & 2.01 & $0.86-4.69$ & 0.107 \\
\hline 5 and over & 2.88 & $1.13-7.34$ & 0.026 \\
\hline Number of self-reported morbidities & 0.99 & 0.93-1.07 & 0.939 \\
\hline \multicolumn{4}{|l|}{ BADL } \\
\hline Independent & & 1 & \\
\hline Dependent & 1.13 & $0.67-1.91$ & 0.649 \\
\hline \multicolumn{4}{|l|}{ IADL } \\
\hline Independent & & 1 & \\
\hline Dependent & 1.38 & $0.87-2.18$ & 0.169 \\
\hline \multicolumn{4}{|l|}{ Frailty } \\
\hline Not frail & & 1 & \\
\hline Pre-frail & 1.05 & $0.64-1.72$ & 0.860 \\
\hline Frail & 1.16 & $0.60-2.23$ & 0.668 \\
\hline
\end{tabular}

\section{DISCUSSION}

The prevalence of female elderly in the research sample is consistent with studies in the community in Ribeirão Preto/São Paulo (66.1\%) (BALDONI et al., 2014) and Belo Horizonte/Minas Gerais, (59.6\%) (FIALHO et al., 2014). The same play for the highest percentage of elderly aged between 60 -70 years (OLIVEIRA et al., 2013; TESTON; ROSSI; MARCON, 2013). Concerning marital status, the predominance of married was lower than that obtained in Belo Horizonte/Minas Gerais (52.8\%) (FIALHO et al., 2014).

As for education, research also showed that most elderly reported having one to four years of study (FERREIRA; ANTUNES; ANDRADE, 2013; FILAHO et al., 2014.). The highest percentage of individual monthly income of one minimum wage obtained in this investigation does not suit with a study of elderly in the city of Montes Claros/Minas Gerais, in which the majority $(70.5 \%)$ received up to one minimum wage (OLIVEIRA et al., 2013).

Regarding access to health services, a similar data to this study was identified in the National Health Survey, in which $79.3 \%$ of elderly people accessed the same place or the same doctor when they needed care (GEOGRAPHY AND STATISTICS BRAZILIAN INSTITUTE, 2015). The use of health services involves factors associated with the services availability, the access 
conditions, quality of care and the relationship of the population with services (DELLAROZA et al., 2013.); are aspects that could justify the result.

Concerning the medical consultation, a similar percentage was found in a national survey (85.3\%) (GEOGRAPHY AND STATISTICS BRAZILIAN INSTITUTE, 2015); and higher in the study among the elderly of Belo Horizonte/MG community, in which it was found that in the last 12 months $92.4 \%$ consulted the doctor at least once (FIALHO et al., 2014). The increase in the elderly population leads to higher prevalence of NCDs and consequently to increased demand for health services and medicine (DELLAROZA et al., 2013; CABRELLI et al., 2014.).

The data obtained in this study are consistent with research in the city of Carlos Barbosa/RS (72.3\%) (DAL OIZZOL et al., 2012) and Quixadá/Ceará region (70.6\%) (SILVA et al., 2012) regarding the use of continuous medication among the elderly. The age group between 65 to 69 years annually consumes an average of 13.6 drugs, while aged 80 to 84 years come to consume 18.2 per year (SILVA; MACEDO, 2013). It is worth mentioning that many drugs may increase the risk of adverse reactions, incorrectly use by the elderly, as well as increasing the risk of morbidity and mortality (SILVA et al., 2012). Being a complex parameter that involves the responsibility of health professionals, patients, and families, the rational use of drugs by the elderly has become a major challenge for public health in Brazil (KHALIL; RODRIGUES, 2015). Thus, the knowledge about drug use by this population is essential to perform redefinitions in public policies aimed at improving the living conditions and health of the elderly (KHALIL; RODRIGUES, 2015; MACEDO; SILVA, 2013).

The percentage of drug acquisition had shown less than that of the population attended by the Unified Health System (45.0\%) (VIACAVA, 2010); and to the research among the elderly of Ribeirão Preto/São Paulo community (46.8\%), where a higher percentage acquired all remedies for free (BALDONI et al., 2014.). A survey among elderly of Bagé/Rio Grande do Sul community found that $45.0 \%$ bought their medicines (TAVARES et al., 2013), a lower value than the obtained in the present study. The low availability of generic and similar to the public health system interfere with the access to medicines and in this situation, the elderly tend to buy them in private pharmacies (VIANA et al., 2015.); a fact that can reduce funds for food and other basic necessities, and it also reflects negatively on the health status and quality of life of this population (GAUTEIRO et al., 2013).

Most seniors reported having been to the dentist for the last three years or over, a result similar to the National Oral Health Survey (53.5\%) (FERREIRA; ANTUNES; ANDRADE, 2013); but inferior than a research in Montes Claros/Minas Gerais (61.9\%) (OLIVEIRA et al., 2013). In Brazil, especially in the public service, there are still few of dental care services to the elderly. The need to develop a health promotion policy aimed at this segment of the population is observed in several studies that prove the lack of such services (SOUZA et al., 2012; MOURA et al., 2014.). Thus, the precariousness of the public service, as well as the lack of access to health insurance or private offices, contribute to the elderly neglect their oral health (MOURA et al., 2014).

It is noteworthy that $16.9 \%$ of respondent elderly used health services in the two weeks preceding the interview. National Health Survey data indicate, overall, a higher percentage $(25 \%)$ among people aged 60 years and over (GEOGRAPHY AND STATISTICS BRAZILIAN INSTITUTE, 2015); while among elderly practitioners of physical activity, (71.5\%) were observed higher values (VIRTUOSO et al., 2012). The expansion of supply and reorganization of health services that occurred in recent years contributed to better access of elderly to these services (VIRTUOSO et al., 2012; OLIVEIRA et al., 2012.).

It should be mentioned that despite the income, illness, disability, and fragility variables did not remain associated in the final regression model; literature (ALMEIDA, 2015; ROCHAT et al, 2010; LOUVISION et al., 2008; FIALHO et al., 2014) shows the relationship between these aspects and the use of health services in the last two weeks.

The Polypharmacy present in this study was associated with greater use of health services among the elderly. Research conducted in the municipalities of Rio de Janeiro/RJ and Belo Horizonte/Minas Gerais identified that the increased use of drugs was associated with the elderly who underwent more medical consultations and had hospitalization history in the last 12 months (SILVA et al., 2012). Research among elderly living in urban and rural areas in Rio Grande do Sul/RS found a positive association between polypharmacy and the use of health services (DAL PIZZOL et al., 2012). Increased access to health services contributes to a greater identification of NCDs, and consequently to an increase in the number of prescript drugs (DAL PIZZOL et al., 2012). 
Thus, the discussion and adoption of clinical protocols by the health services and the promotion of continuing education of the professionals in the elder care demands are relevant. The prescription of drugs for the elderly should be conducted in accordance by the overall health conditions of the elderly, and not only according to the treatment of a particular disease, reflecting a posture that minimizes Polypharmacy and prescribing unsafe drugs to the elderly (NEVES et al., 2013).

The association between the use of health services in the last two weeks and self-perceived negative health is according to research conducted in São Paulo/SP (LOUVISON et al., 2008); and a systematic review that found that variables such as hospitalizations and physician visits were associated with self-assessment negative health (PAGOTTO; BACHION; SILVEIRA, 2013). Also, data from the National Sample by Domicile Survey (NSDS) between 1998 and 2008 showed that the better the state of health of the elderly, the demand for health services for the treatment of disease is reduced approximately from 11 to $12 \%$ (ALMEIDA, 2015).

\section{CONCLUSIONS}

The most elderly went to the same service and professional; searched for medical appointments in the last year and a dentist for more than three years; and made use of continuous medication. The use of health services in the last two weeks represented $16.9 \%$ and was associated with polypharmacy and the perception of negative health.

The study presents as limitation the crosssectional design, which does not allow establishing causal relationships; and the use of questionnaires that may underestimate or overestimate some information, although widely reported in studies in the scientific literature.

This study contributes to knowledge about the access and use of health care of the elderly services in the investigated scenario; presenting the factors that influence the use of health services, and promote understanding from the perception of the consumption standard, which enables the planning of health actions as the presented characteristics.

\section{ACKNOWLEDGMENTS}

Fundação de Amparo à Pesquisa do Estado de Minas Gerais (FAPEMIG), Brazil, process $\mathrm{n}^{\circ}$ APQ-02035-14.

RESUMO: Objetivou-se descrever as características relacionadas ao acesso e à utilização dos serviços de saúde; e verificar os fatores associados ao uso dos serviços entre idosos. Estudo transversal e analítico, conduzido com 705 idosos de área urbana em Uberaba-MG. Foram utilizados: instrumento estruturado referente aos dados socioeconômicos, Escalas de Katz e Lawton e Brody e Fenótipo de Fragilidade de Fried; e questionário da Pesquisa Nacional por Amostra de Domicílios para o acesso e a utilização dos serviços de saúde. Procedeu-se às análises descritiva e regressão logística $(\mathrm{p}<0,05)$. Constatou-se que $86,2 \%$ acessavam o mesmo lugar ou mesmo médico quando precisavam de atendimento; $86,5 \%$ consultaram médico nos últimos 12 meses; 85,2\% faziam uso de medicamentos contínuos, desses 40,4\% receberam parte dos seus medicamentos; e os que não receberam todos os medicamentos, 86,1\% efetuaram a compra. A maioria foi ao dentista pela última vez há 3 anos ou mais (54,2\%), enquanto que 21,7\% há menos de 1 ano; e 16,9\% utilizaram os serviços de saúde nas duas últimas semanas anteriores à entrevista. Consolidaram-se como fatores associados ao uso dos serviços de saúde a polifarmácia (OR: 2,88; p=0,026) e a percepção de saúde negativa $(O R$ : 1,89; p=0,009). O conhecimento do padrão de consumo e fatores relacionados possibilita a organização dos serviços conforme as características apresentadas.

PALAVRAS-CHAVE: Idoso. Sistema de saúde. Serviços de saúde para idosos. Acesso aos serviços de saúde.

\section{REFERENCES}

ALMEIDA, A. N. O acesso aos serviços de saúde pelos idosos no Brasil com base na Pesquisa Nacional por Amostra de Domicílios (PNAD) entre 1998 e 2008. Jornal Brasileiro de Economia da Saúde, São Paulo, v. 7, n. 1, p. 43-52, 2015.

ASSIS, M. M. A.; JESUS, W. L. A. Acesso aos serviços de saúde: abordagens, conceitos, políticas e modelo de análise. Ciências \& Saúde Coletiva, Rio de Janeiro, v. 17, n. 11, p. 2865-2875, 2012. 
BALDONI, A. O. et al. Dificuldades de acesso aos serviços farmacêuticos pelos idosos. Revista de Ciências Farmacêuticas Básica e Aplicada, Araraquara, v. 35, n. 4, p. 615-621, 2015.

BASTOS, G. A. N.; HARZHEIM, E.; SOUSA. A. L. Prevalência e fatores associados à consulta médica entre adultos de uma comunidade de baixa renda do Sul do Brasil. Epidemiologia e Serviços de Saúde, Brasília, v. 23, n. 3, p. 409-420, 2014. https://doi.org/10.5123/S1679-49742014000300004

BERTOLUCCI, P. H. F. et al. O mini exame do estado mental em uma população geral: impacto da escolaridade. Arquivos de Neuropsiquiatria, São Paulo, v. 52, n. 1, p. 1-7, 1994.

https://doi.org/10.1590/S0004-282X1994000100001

CABRELLI, R. et al. Idosos na unidade de saúde da família: morbidade e utilização de serviços de saúde.

Revista da Rede de Enfermagem do Nordeste, Ceará, v. 15, n. 1, p. 89-98, 2014.

https://doi.org/10.15253/2175-6783.2014000100012

DAL PIZZOL, T. S. et al. Uso de medicamentos entre idosos residentes em áreas urbanas e rurais de município no Sul do Brasil: um estudo de base populacional. Cadernos de Saúde Pública, Rio de Janeiro, v. 28, n. 1, p. 104-114, 2012.

DELlAROZA, M. S. G. et al. A. Associação de dor crônica com uso de serviços de saúde em idosos residentes em São Paulo. Revista de Saúde Pública, São Paulo, v. 47, n. 5, p. 914-22, 2013.

https://doi.org/10.1590/S0034-8910.2013047004427

FERREIRA, C. O; ANTUNES, J. L. F.; ANDRADE, F. B. Fatores associados a utilização dos serviços odontológicos por idosos brasileiros. Revista de Saúde Pública, São Paulo, v. 47, n. 3, p. 90-97, 2013. https://doi.org/10.1590/S0034-8910.2013047004721

FIALHO, C. B. et al. Capacidade funcional e uso de serviços de saúde por idosos da região metropolitana de Belo Horizonte, Minas Gerais, Brasil: um estudo de base populacional. Cadernos de Saúde Pública, Rio de Janeiro, v. 30, n. 3, p. 599-610, 2014.

FRIED, L. P. et al. Frailty in older adults evidence for a phenotype. The Journals of Gerontology. Series A: Biological Sciences and Medical Sciences, v. 56, n. 3, p. M146-M157, 2001.

https://doi.org/10.1093/gerona/56.3.M146

GAUTERIO, D. P. et al. Uso de medicamentos por pessoas idosas na comunidade: proposta de ação de enfermagem. Revista Brasileira de Enfermagem, Brasília, v. 66, n. 5, p. 702, 2013.

https://doi.org/10.1590/S0034-71672013000500010

HERNANDES, E. S. C. et al. Health insurance coverage of the elderly and socioepidemiological characteristics associated. Revista de Saúde Pública, São Paulo, v. 46, n. 6, p. 1030-1038, 2012.

https://doi.org/10.1590/S0034-89102012000600013

INSTITUTO BRASILEIRO DE GEOGRAFIA E ESTATÍSTICA. Pesquisa Nacional de Saúde 2013: acesso e utilização dos serviços de saúde, acidentes e violências. Rio de Janeiro: IBGE, 2015.

INSTITUTO BRASILEIRO DE GEOGRAFIA E ESTATÍSTICA. Pesquisa Nacional por amostra de domicílios. Um panorama da saúde no Brasil: acesso e utilização dos serviços, condições de saúde e fatores de risco e proteção à saúde 2008. Rio de Janeiro: IBGE, 2010.

INSTITUTO BRASILEIRO DE GEOGRAFIA E ESTATÍSTICA. Sinopse do Censo demográfico. Rio de Janeiro; 2012. 
KHALIL, S. S; RODRIGUES, M. C. S. Polifarmácia em idosos do Brasil: reflexão à luz de problemáticas e perspectivas. Revista Ibero-Americana de Saúde Envelhecimento, Évora, v.1, n.2, p. 146-154, 2015. https://doi.org/10.24902/r.riase.2015.1(2).146

LINO, V. T. S. et al. Adaptação transcultural da Escala de Independência em Atividades de Vida Diária (Escala de Katz). Cadernos de Saúde Pública, Rio de Janeiro, v. 24, n. 1, p. 103-12, 2008.

LOUVISON, M. C. P. et al. Desigualdades no uso e acesso aos serviços de saúde entre idosos do município de São Paulo. Revista de Saúde Pública, São Paulo, v. 42, n. 4, p. 733-740, 2008. https://doi.org/10.1590/S003489102008000400021

MOURA, L. K. B. et al. Produção científica sobre saúde bucal de idosos no Brasil. Revista Interdisciplinar, Itabaiana, v. 7, n. 4, p. 179-188, 2014.

NEVES, S. J. F. et al. Epidemiologia do uso de medicamentos entre idosos em área urbana do Nordeste do Brasil. Revista de Saúde Pública, São Paulo, v. 47, n. 4, p. 759-768, 2013. https://doi.org/10.1590/S00348910.2013047003768

OLIVEIRA, R. F. R. et al. Idosos: uso dos serviços odontológicos, comportamentos relacionados à saúde e condições subjetivas de saúde entre. Unimontes Científica, Montes Claros, v. 14, n. 1, p. 202-218, 2012.

PAGOTTO, V.; BACHION, M. M.; SILVEIRA, E. A. Autoavaliação da saúde por idosos brasileiros: revisão sistemática da literatura. Revista Panamericana de Salud Publica, Washington, v. 33, n. 4, p. 302-310, 2013. https://doi.org/10.1590/S1020-49892013000400010

PEGORARI, M. S.; TAVARES, D. M. S. Factors associated with the frailty syndrome in elderly individuals living in the urban area. Revista Latino-Americana de Enfermagem, Ribeirão Preto, v. 22, n.5, p. 874-882, 2014. https://doi.org/10.1590/0104-1169.0213.2493

PILGER, C.; MENON, M. U.; MATHIAS, T. A. F. Utilização de serviços de saúde por idosos vivendo na comunidade. Revista da Escola de Enfermagem da USP, São Paulo, v. 47, n. 1, p. 213-220, 2013. https://doi.org/10.1590/S0080-62342013000100027

ROCHAT, S. F. et al. Frailty and use of health and community services by community-dwelling older men: the Concord Health and Ageing in Men Project. Age and Ageing, Oxford, v. 39, p.228-33, 2010. https://doi.org/10.1093/ageing/afp257

SANTOS, R. L.; VIRTUOSO JÚNIOR, J. S. Confiabilidade da versão brasileira da escala de atividades instrumentais da vida diária. Revista Brasileira em Promoção da Saúde, Fortaleza, v. 21, n. 4, p. 290-296, 2008. https://doi.org/10.5020/18061230.2008.p290

SILVA, A. L. et al. Utilização de medicamentos por idosos brasileiros, de acordo com a faixa etária: um inquérito postal. Cadernos de Saúde Pública, Rio de Janeiro, v. 28, n. 6, p. 1033-1045, 2012. https://doi.org/10.1590/S1415-790X2012000200016

SILVA, E. A.; MACEDO, S. L. C. Polifarmácia em idosos. Revista Saúde e Pesquisa, Maringá, v. 6, n. 3, p. 477-486, 2013.

SILVA, G. O. B. et al. Uso de medicamentos contínuos e fatores associados em idosos de Quixadá, Ceará. Revista Brasileira de Epidemiologia, São Paulo, v. 15, n. 2, p. 386-95, 2012.

SOUZA, E. H. A. et al. Raça e o uso dos serviços de saúde bucal por idosos. Ciência \& Saúde Coletiva, Rio de Janeiro, v.17, n.8, p. 2063-2070, 2012. 
TAVARES, N. U. L. et al. Fatores associados à baixa adesão ao tratamento medicamentoso em idosos. Revista de Saúde Pública, São Paulo, v.47; n. 6; p.1092-101, 2013. https://doi.org/10.1590/S003489102013000901092

TEIXEIRA, E. T. L.; OLIVEIRA, C. T.; SILVA, S. S. Obstáculos ao acesso à saúde do idoso: o olhar dos profissionais de saúde. Revista Enfermagem Herediana, Lima, v. 4, n. 2, p. 56-63, 2011.

TESTON, E. F.; ROSSI, R. M.; MARCON, S. S. Use of health services by residents at a seniors-only living facility. Revista da Escola de Enfermagem da USP, São Paulo, v. 47, n. 5, p. 1122-1128, 2013. https://doi.org/10.1590/S0080-623420130000500016

VERAS, R. Envelhecimento populacional contemporâneo: demandas, desafios e inovações. Revista de Saúde Pública, São Paulo, v. 43, n. 3, p. 548-554, 2009. https://doi.org/10.1590/S0034-89102009000300020

VIANA, P. K. et al. Acesso a medicamentos de uso contínuo entre idoso, Brasil. Revista de Saúde Pública, São Paulo, v.49, n. 1, p.1-10, 2015.

VIACAVA, F. Acesso e uso de serviços de saúde pelos brasileiros: estudo realizado a partir dos dados da PNAD/IBGE analisa desigualdades geográficas e de renda e monitora o desempenho das políticas de saúde. RADIS, Rio de Janeiro, n. 96, p.12-9, 2010.

VIRTUOSO, J. F. et al. Perfil de morbidade referida e padrão de acesso a serviços de saúde por idosos praticantes de atividade física. Ciência \& Saúde Coletiva, Rio de Janeiro, v. 17, n. 1, p. 23-31, 2012. 